NASA/TM-2004-212918

Experimental Investigation of a Multiplex Fuel Injector Module With Discrete Jet Swirlers for Low Emission Combustors

Robert Tacina

Glenn Research Center, Cleveland, Ohio

Chien-Pei Mao

Turbine Fuel Technologies Goodrich Corporation, West Des Moines, Iowa

Changlie Wey

QSS Group, Inc., Cleveland, Ohio 
Since its founding, NASA has been dedicated to the advancement of aeronautics and space science. The NASA Scientific and Technical Information (STI) Program Office plays a key part in helping NASA maintain this important role.

The NASA STI Program Office is operated by Langley Research Center, the Lead Center for NASA's scientific and technical information. The NASA STI Program Office provides access to the NASA STI Database, the largest collection of aeronautical and space science STI in the world. The Program Office is also NASA's institutional mechanism for disseminating the results of its research and development activities. These results are published by NASA in the NASA STI Report Series, which includes the following report types:

- $\quad$ TECHNICAL PUBLICATION. Reports of completed research or a major significant phase of research that present the results of NASA programs and include extensive data or theoretical analysis. Includes compilations of significant scientific and technical data and information deemed to be of continuing reference value. NASA's counterpart of peerreviewed formal professional papers but has less stringent limitations on manuscript length and extent of graphic presentations.

- TECHNICAL MEMORANDUM. Scientific and technical findings that are preliminary or of specialized interest, e.g., quick release reports, working papers, and bibliographies that contain minimal annotation. Does not contain extensive analysis.

- CONTRACTOR REPORT. Scientific and technical findings by NASA-sponsored contractors and grantees.
- CONFERENCE PUBLICATION. Collected papers from scientific and technical conferences, symposia, seminars, or other meetings sponsored or cosponsored by NASA.

- SPECIAL PUBLICATION. Scientific, technical, or historical information from NASA programs, projects, and missions, often concerned with subjects having substantial public interest.

- TECHNICAL TRANSLATION. Englishlanguage translations of foreign scientific and technical material pertinent to NASA's mission.

Specialized services that complement the STI Program Office's diverse offerings include creating custom thesauri, building customized databases, organizing and publishing research results ... even providing videos.

For more information about the NASA STI Program Office, see the following:

- Access the NASA STI Program Home Page at http://www.sti.nasa.gov

- E-mail your question via the Internet to help@sti.nasa.gov

- Fax your question to the NASA Access Help Desk at 301-621-0134

- Telephone the NASA Access Help Desk at 301-621-0390

- Write to:

NASA Access Help Desk

NASA Center for AeroSpace Information 7121 Standard Drive

Hanover, MD 21076 
NASA/TM-2004-212918

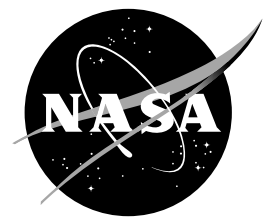

\section{Experimental Investigation of a Multiplex Fuel Injector Module With Discrete Jet Swirlers for Low Emission Combustors}

Robert Tacina

Glenn Research Center, Cleveland, Ohio

Chien-Pei Mao

Turbine Fuel Technologies Goodrich Corporation, West Des Moines, Iowa

Changlie Wey

QSS Group, Inc., Cleveland, Ohio

Prepared for the 42nd Aerospace Sciences Meeting and Exhibit sponsored by the American Institute of Aeronautics and Astronautics Reno, Nevada, January 5-8, 2004

National Aeronautics and

Space Administration

Glenn Research Center 
Available from

NASA Center for Aerospace Information 7121 Standard Drive

Hanover, MD 21076
National Technical Information Service 5285 Port Royal Road Springfield, VA 22100

Available electronically at http://gltrs.grc.nasa.gov 


\title{
EXPERIMENTAL INVESTIGATION OF A MULTIPLEX FUEL INJECTOR MODULE WITH DISCRETE JET SWIRLERS FOR LOW EMISSION COMBUSTORS
}

\author{
Robert Tacina \\ National Aeronautics and Space Administration \\ Glenn Research Center \\ Cleveland, Ohio 44135 \\ Chien-Pei Mao \\ Turbine Fuel Technologies Goodrich Corporation \\ West Des Moines, Iowa 50265 \\ Changlie Wey \\ QSS Group, Inc. \\ Cleveland, Ohio 44135
}

\begin{abstract}
A low-NOx emissions combustor concept has been demonstrated in flame-tube tests. A lean-direct injection (LDI) concept was used where the fuel is injected directly into the flame zone and the overall equivalence ratio of the mixture is lean. The LDI concept described in this report is a multiplex fuel injector module containing multipoint fuel injection tips and multi-burning zones. The injector module comprises 25 equally spaced injection tips within a $76 \mathrm{x}$ $76 \mathrm{~mm}$ area that fits into the flame-tube duct. The air swirlers were made from a concave plate on the axis of the fuel injector using drilled holes at an angle to the axis of the fuel injector. The NOx levels were quite low and are greater than 70\% lower than the 1996 ICAO standard. At an inlet temperature of $810 \mathrm{~K}$, inlet pressure of $2760 \mathrm{kPa}$, pressure drop of $4 \%$ and a flame temperature of $1900 \mathrm{~K}$ with JP8 fuel, the NOx emission index was 9. The 25-point injector module exhibited the most uniform radial distribution of fuel-air mixture and NOx emissions in the flame tube when compared to other multipoint injection devices. A correlation is developed relating the $\mathrm{NOx}$ emissions to inlet temperature, inlet pressure, equivalence ratio and pressure drop.
\end{abstract}

\section{INTRODUCTION}

The low emissions combustor development described in this paper was done as part of the NASA Smart Efficient Components Program. The objective of this combustor project under Smart Efficient Components is to achieve an 80\% NOx reduction relative to the 1996 ICAO standards and to maintain carbon monoxide and unburned hydrocarbons at their current low levels at low power conditions. A reduction in NOx emissions is important because of their effect as a greenhouse gas.
NOx emitted from aircraft has a complicated effect on the environment and can react with other greenhouses gases such as ozone and methane and change the radiative heat balance, see Wey and Maurice. ${ }^{1}$ The technologies developed and demonstrated will be applicable to NASA and DOD advanced aircraft engine development programs, and to turbine engine industry development programs.

Low NOx combustors can be classified into rich burn and lean burn concepts. Lean burn combustors can be further classified into Lean-Premixed-Prevaporized (LPP) and Lean Direct Injection (LDI). In both LPP and LDI concepts all of the combustor air, except for liner cooling flow, enters through the combustor dome so that the combustion occurs at the lowest possible flame temperature. The LPP concept has been shown to have the lowest NOx emissions, see Tacina, ${ }^{2}$ but for advanced high-pressure ratio engines the possibility of auto-ignition or flashback precludes its use. LDI differs from LPP in that the fuel is injected directly into the flame zone and thus it does not have the potential for auto-ignition or flashback and should have greater stability. NOx emissions from an LDI can approach those from a LPP but since LDI is not premixed and pre-vaporized, it must provide good atomization and mixing of the fuel quickly and uniformly to maintain low flame temperatures and NOx levels comparable to those of LPP.

To provide good atomization and mixing of the fuel, the LDI concept described in this report is a multiplex fuel injector module containing multiple fuel injection tips and multi-burning zones. Previously a multiplex fuel injector concept was evaluated in flame-tube tests ${ }^{3}$ that had 49 fuel injectors in a $76 \times 76 \mathrm{~mm}$ area. This previous fuel injector module had two fuel circuits for fuel staging with every other fuel injector in a 
checkerboard pattern on a fuel circuit. The NOx levels were low (greater than $70 \%$ lower than the 1996 ICAO standard) and it was found that when only one fuel circuit of 25 out of the 49 fuel injectors was used the NOx levels were the same as when all the fuel injectors were used. The injector module for the present study comprises 25 injection tips mounted within the $76 \mathrm{x}$ $76 \mathrm{~mm}$ area. Each of the fuel injection tips is a unique simplex airblast atomizer design that simplifies the fuel injector construction. The air swirlers are also a unique design of discrete air jets that are made from a concave plate on the axis of the fuel injector using drilled holes at an angle to the axis. The multiplex injector module not only provides quick and uniform mixing; it also produces small multi-burning zones for reduced residence time resulting in low NOx formation.

The new 25-point Multiplex Fuel Injector Module, MPLX25, was evaluated in flame-tube testing and compared to he previously developed multipoint injector concepts. Test conditions included inlet air temperatures up to $810 \mathrm{~K}$, inlet pressures up to 2760 $\mathrm{kPa}$ and the test fuel was JP8.

\section{MULTIPLEX FUEL INJECTOR MODULE}

The fuel injector module is illustrated in Fig. 1. It comprises 25 closely spaced injection tips that are designed to fit within a $76 \mathrm{~mm} \times 76 \mathrm{~mm}$ test area. The center-to-center distance between the injection tips is $14.4 \mathrm{~mm}$. Each of the injection tips is a fully functional simplex airblast atomizer, containing a pressure swirl atomizer in the center and a discrete-jet air swirler on the outside.

To minimize manufacturing cost, a unique configuration is employed for the design of the atomizer and air swirler. The pressure swirl atomizer contains only two components: a spherical sealing ball and a distributor cone. To construct the atomizer, a sealing ball is pressed into a distributor cone and the assembled distributor cone is laser-welded onto a fuel supply tube to form a pressure swirl atomizer tip. All 25 pressure atomizer tips are brazed onto a fuel manifold ready to be inserted into a face plate that contains 25 discrete-jet air swirlers. The flow number, $\mathrm{FN}_{\mathrm{SI}}$, per nozzle is $0.053 \mathrm{~mm}^{2}\left(\mathrm{FN}_{\mathrm{US}}=1.0\right)$, flow numbers definitions from Lefebvre. ${ }^{4}$ The air swirlers are made by drilling two rows of holes through the swirler body at an angle to the tip axis. The effective area of the air swirler array is $630 \mathrm{~mm}^{2}$. Figure 2 provides a close view of the fuel manifold, air swirler and pressure atomizer tip assembly and Fig. 3 shows the assembly installed in the test rig housing.

\section{Spray Characteristics and Measurements}

During injector tip development, detailed measurements were made to help evaluate the performance of various tip configurations, including spray patternation, droplet size and velocity, ignition, combustion stability and acoustic level. Measurements were made for each injector tip configuration at various operating conditions under atmospheric conditions. The spray pattern is uniform and without streaks.

For spray characterization, droplet size and velocity measurements were made to determine whether the spray dynamic structure is best suited to meet the ignition and combustion stability requirements. Figs. $4 \mathrm{a}$ and $4 \mathrm{~b}$ show an example of the radial distribution of Sauter mean diameter (SMD) and droplet mean axial velocity for the comparison of spray characteristics at the minimum operating condition for rig tests. The measurements were conducted at $38 \mathrm{~mm}$ from the nozzle face at a fuel flow rate of $1.54 \mathrm{~kg} /$ hour, fuel pressure drop differential of $57 \mathrm{kPa}$, and an air pressure drop of $67 \mathrm{kPa}$. The droplet sizes appear to be quite small across the spray with small SMD values of less than $20 \mu \mathrm{m}$ in the center and SMD values of near $60 \mu \mathrm{m}$ at the outside edge. The average of the SMD values across the spray is approximately $30 \mu \mathrm{m}$. The SMD values generally decrease with increasing fuel and air pressures, and since the combustion tests have higher fuel flows and higher ambient pressures, the drop sizes during the combustion tests will be smaller. The velocity profile generally exhibits a double-peak distribution. The maximum velocity appears to be located at a certain radial distance from the center axis. In the center of the spray, the droplet velocity is much slower, with smaller drop sizes that vaporize quickly to provide stable combustion.

\section{EXPERIMENTAL FACILTY}

A schematic of the experimental facility is shown in Fig. 5. The incoming combustion air is heated by a non-vitiated heat exchanger to a maximum temperature of $840 \mathrm{~K}$ and a maximum pressure of $3000 \mathrm{kPa}$. The flow is measured by a venturi meter, and fuel-flow rate is measured by a turbine meter. The fuel-injector module is mounted in a stainless-steel pipe with a $152-\mathrm{mm}$ inside diameter. The fuel and air mixture is injected into a flame tube that has a square cross section of $76.2 \mathrm{~mm}$ on a side. The flame-tube flow passage is made of zirconia $\left(\mathrm{ZrO}_{2}\right), 12 \mathrm{~mm}$ thick, which is housed in a $152-\mathrm{mm}$ diameter pipe. The gap between the zirconium tube and the pipe is filled with an alumina $\left(\mathrm{Al}_{2} \mathrm{O}_{3}\right)$ casting. The outside of the pipe is cooled by a 
water coil. The test section is 300-mm long, followed by a water-quench section and back-pressure valve. Gas sampling is done $200 \mathrm{~mm}$ from the fuel-injector exit. A three-hole, water-cooled probe was used, with the holes equally spaced across the diameter of the flame tube. There is a single-hole traversing probes located at $100 \mathrm{~mm}$ from the fuel-injector exit for radialprofile measurements. The concentrations of $\mathrm{O}_{2}, \mathrm{CO}$, $\mathrm{CO}_{2}, \mathrm{HC}$ (as $\mathrm{CH}_{4}$ ), $\mathrm{NO}$, and $\mathrm{NOx}$ are measured by standard, gas-analysis procedures, $\mathrm{SAE}^{5}$ : chemiluminescence for $\mathrm{NO}$, nondispersive infrared absorption for $\mathrm{CO}$ and $\mathrm{CO}_{2}$, flame ionization for $\mathrm{HC}$, and paramagnetic analysis for $\mathrm{O}_{2}$. The $\mathrm{NO}_{2}-\mathrm{NO}$ converter is calibrated using standard $\mathrm{NO}_{2}$ to verify that conversion efficiencies are greater than $96 \%$. The overall accuracy of the emission measurements are estimated to be within $90 \%$. This is based on the repeatability of data when the same configuration was tested on different days and with at least one change of configurations between tests of the same configuration.

\section{RESULTS AND DISCUSSION}

The log of the NOx emissions is plotted versus the equivalence ratio (which is the fuel-air ratio, determined from the emissions measurements, divided by 0.068 ) in Figs. $6 a$ and $6 b$. The NOx values are given in terms of emission index, $\mathrm{g} \mathrm{NO}_{2} / \mathrm{kg}$ fuel, where the emissions of $\mathrm{NO}$ are calculated as $\mathrm{NO}_{2}$. There are four values of inlet temperature: $505 \mathrm{~K}, 615 \mathrm{~K}, 730 \mathrm{~K}$, and $810 \mathrm{~K}$; three values of pressure: $1030 \mathrm{kPa}, 1380 \mathrm{kPa}$, and $2760 \mathrm{kPa}$; and three values of pressure drop: 3,4 , and 5 percent of the inlet pressure. The range of the equivalence ratio shown is limited at the high values by the facility requirements and at the low end by good combustion efficiency. The combustion efficiency is greater than $99.9 \%$ for all points plotted. The equivalence ratio obtained from the emissions measurements was, in general, within $2 \%$ of the metered value, with the highest value being $4.5 \%$ high and the lowest value being $4.3 \%$ low compared to the metered value.

The major features shown in Fig. 6a are that the NOx levels are low over the range of test conditions and that the NOx emissions follow the expected trends of increasing with increasing inlet pressure and temperature and decreasing with increasing air pressure drop. The plots at the various inlet conditions are all smooth, with the slopes of the plots being nearly linear (on a log plot). Some plots show an increase in slope with increasing equivalence ratio. A plot of $\mathrm{NOx}$ emissions versus the adiabatic temperature (adiabatic equilibrium temperature determined from the emission measurements), Fig. 6b, is essentially the same as the plot using equivalence ratio and does not collapse the data.

The NOx data are correlated in two ways. The first uses a standard correlation, developed at NASA GRC, based on many configurations tested in the Advanced Subsonic Technology and UEET Programs, both from industry and NASA configurations, Wey ${ }^{6}$ :

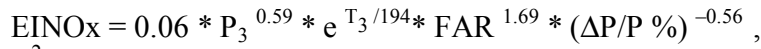
$\mathrm{R}^{2}=0.90$

$\left(\mathrm{T}_{3}\right.$ in $\mathrm{K}, \mathrm{P}_{3}$ in $\mathrm{kPa}$ and $\mathrm{FAR}$ is the fuel-air ratio)

Another fit can be obtained if the exponents are calculated from the multiplex data,

EINOx $=0.17 * \mathrm{P}_{3}{ }^{0.45} * \mathrm{e}^{\mathrm{T}}{ }_{3} / 200 * \mathrm{FAR}^{1.40} *(\Delta \mathrm{P} / \mathrm{P} \%)^{-0.35}$, $\mathrm{R}^{2}=0.94$

Figure 7 shows the comparison of the NOx data between the measurement and calculation from the two correlation equations. The inlet pressure exponent for correlation equation 2 is lower than the standard NASA correlation, equation 1 , and approximately equal to the generally accepted value of 0.5 . The effects of inlet temperature and fuel-air ratio in equations 2 are also lower than the standard NASA correlation.

On closer inspection of Fig. 7, it can be seen that equation 2 is a better fit for the tested data only because there is more low power data than data at high power conditions. Equation 1 estimates $\mathrm{NOx}$ emissions more accurately at high power conditions and thus equation 1 is considered the best fit for the EINOx calculations. The NOx emissions calculated over a typical landing takeoff cycle would be greater than $70 \%$ below the 1996 ICAO standard.

From Fig. 6a, a higher air-pressure drop through the module decreases NOx emissions. The higher pressure drop (since the flow area is fixed) is obtained by increasing the air mass flow and, consequently, the combustion residence time is decreased. If NOx is a linear function of residence time, as given in Anderson, ${ }^{7}$ and mass flow varies with the square root of pressure drop, then the NOx production varies inversely with the square root of pressure drop. Additionally higher pressure drop increases turbulence, which in turn increases mixing and could decrease NOx production. A third factor is that, as the air pressure drop increases, the air mass flow increases, and for the same equivalence ratio, the fuel flow increases. This in turn increases the fuel pressure drop, resulting in better atomization and a smaller average drop size, although 
at the fuel pressure drop for high power conditions this effect is probably small. Higher air velocity also decreases the drop sizes as a result of enhanced primary and secondary breakup of the fuel stream.

The carbon monoxide emissions for the various test conditions are shown as a function of equivalence ratio in Fig. 8a and as a function of flame temperature in Fig. 8b. For the carbon monoxide emissions the flame temperature collapses the data. As the inlet temperature decreases the combustor temperature for low carbon monoxide emissions increases. At an inlet temperature of $820 \mathrm{~K}$, a combustor temperature greater than $1500 \mathrm{~K}$ is needed for low carbon monoxide emissions, and a combustor temperature of almost $1700 \mathrm{~K}$ is needed for an inlet temperature of $505 \mathrm{~K}$. Note that a carbon monoxide emission index value of approximately 40 is a $1 \%$ combustion inefficiency. The hydrocarbon values were low (single digit parts per million) when the carbon monoxide values are low. As equivalence or combustor temperature are lowered, first the carbon monoxide values would increase and then as the equivalence ratio was further decreased the hydrocarbon values would increase.

Using the traversing probe at $100 \mathrm{~mm}$ downstream, a radial profile of fuel-air ratio (normalized by the metered fuel-air ratio), and NOx emission index (normalized by the NOx emission index at $200 \mathrm{~mm}$ ) are shown in Figs. 9a and 9b. The inlet temperature, pressure and pressure drop for the data is $810 \mathrm{~K}$, $2760 \mathrm{kPa}$, and $4 \%$, respectively. The fuel distribution (as shown by equivalence ratio) is extremely uniform, with a variation of about $2 \%$. This is the most uniform distribution we have obtained with multipoint configurations. Note that the NOx levels at an axial distance of $100 \mathrm{~mm}$ from the fuel system were approximately the same as at $200 \mathrm{~mm}$. It was observed in ref. 3 that the fuel mixes and reacts very quickly with the airflow, and the fuel concentration is near zero within $20 \mathrm{~mm}$ distance from the injector face.

In Fig. 10, the NOx emissions obtained with the present MPX25 are compared to the previously reported Multiplex 49 point Injector, ${ }^{3}$ MPX49, and the Multi Point Integrated Module (MPIM) data. ${ }^{8}$ The comparison is at the test condition of an inlet temperature of $810 \mathrm{~K}$, an inlet pressure of $2760 \mathrm{kPa}$, and a $4 \%$ pressure drop. The two sets of Multiplex NOx data are very similar and fall in the range of the 25-point (25 fuel injectors) MPIM and are greater than the 36-point MPIM. This is consistent with the data from Ref. 3, when only 25 of the 49 injectors were used and the NOx emissions were approximately the same. Evidently the number of fuel injectors is only one factor that influences the amount of NOx produced. Other factors, such as the intensity of mixing, the position of the flame and the size of the recirculation zone, must also be considered for NOx reduction.

\section{SUMMARY AND CONCLUSIONS}

A low-NOx, multiplex LDI concept has been demonstrated in flame-tube tests. The configuration tested had 25 fuel injectors in the size of a conventional, single fuel injector. Each fuel injector had an axial air swirler for quick mixing of the fuel and air before burning. Each of the fuel injection tips is a unique simplex-air blast-atomizer design that simplifies the fuel injector construction. The air swirlers are also a unique design of discrete air jets with simplified construction. The air swirlers are made from a concave plate on the axis of the fuel injector, using drilled holes at an angle to the axis. Test conditions ranged from inlet temperatures up to $810 \mathrm{~K}$, inlet pressures up to $2760 \mathrm{kPa}$, flame temperatures up to $2100 \mathrm{~K}$, and JP8 fuel. The NOx levels were quite low. At an inlet temperature of $810 \mathrm{~K}$, inlet pressure of $2760 \mathrm{kPa}$, pressure drop of $4 \%$, and a flame temperature of $1900 \mathrm{~K}$, the NOx emission index was 9.

A correlation was developed relating the NOx emission index to inlet temperature, inlet pressure, equivalence ratio, and pressure drop. The dependence on inlet pressure, inlet temperature, fuel-air ratio, and pressure drop are less than the standard correlation. The NOx levels from the 25-point multiplex injector were the same as the previously reported 49-point multiplex injector and approximately the same as a previously reported 25-point MPIM combustor concept. However, the NOx levels were higher than the 36-point MPIM, although at high equivalence ratios the difference in NOx levels was less. The radial distribution of NOx and fuel-air ratio produced by the present 25-point multiplex injector was within $2 \%$ of the mean, and the best among the multipoint configurations tested in our facility. Improvements in the lean limit of good combustion efficiency at low power conditions are needed to make it comparable to conventional combustors.

\section{REFERENCES}

1. Wey, Chowen, C., and Maurice, Lourdes Q., "Exploring Technology and Policy Options For Reducing Aviation's Environmental Impact," AIAA-2003-5993, 1st International Energy Conversion Engineering Conference (IECEC), August, 2003. 
2. Tacina, R.R., (1990). "Low NOx Potential of Gas Turbine Engines," AIAA Paper 90-0550, 28 $8^{\text {th }}$ Aerospace Science Meeting, Reno NV, 1990.

3. Tacina, R., Mao, C-P, and Wey, Changlie. "Experimental Investigation of a Multiplex Fuel Injector Module for Low Emission Combustors," AIAA Paper 2003-0827, 41 ${ }^{\text {th }}$ Aerospace Science Meeting, Reno NV, 2003.

4. Lefebvre, A.H., (1998). Gas Turbine Combustion, Second Edition, Taylor and Francis, Philadelphia, PA, p. 236

5. SAE ARP1533-1996, "Procedure for the Calculation of Gaseous Emissions from Aircraft Turbine Engines."

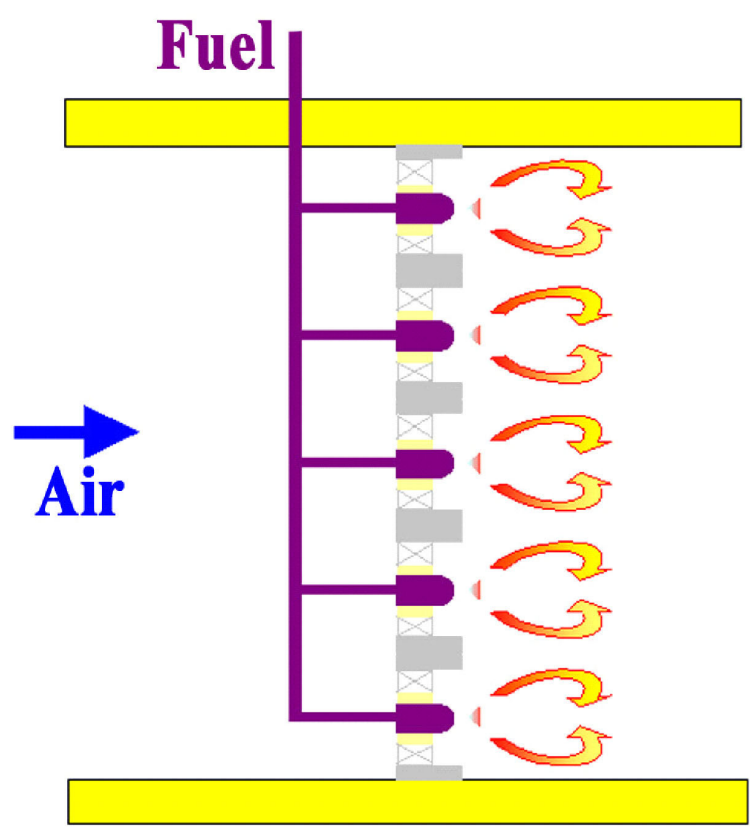

6. Wey, Changlie, (2004), "A High Pressure and High Temperature NOx Correlation," paper in progress.

7. Anderson, D.N., (1975). "Effects of Equivalence Ratio and Dwell Time on Exhaust Emissions from an Experimental Premixing Prevaporizing Burner." ASME Paper 75-GT-69, Gas Turbine Conference \& Products Show, Houston TX, 1975.

8. Tacina, R., Wey, C., Laing, P., Mansour, A , (2001), "A Low NOx Lean-Direct Injection, MultiPoint Integrated Module Combustor Concept for Advanced Aircraft Gas Turbines," Clean Air Conference, Porto, Portugal, NASA/TM-20022111347.

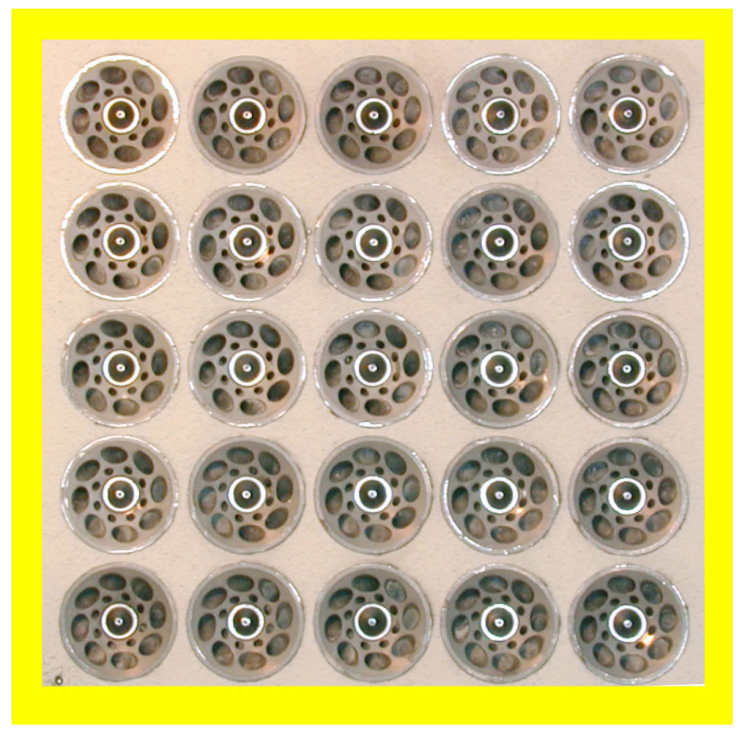

Figure 1 - 25-pt Mltiplex fuel injector with discrete-jet air swirler 


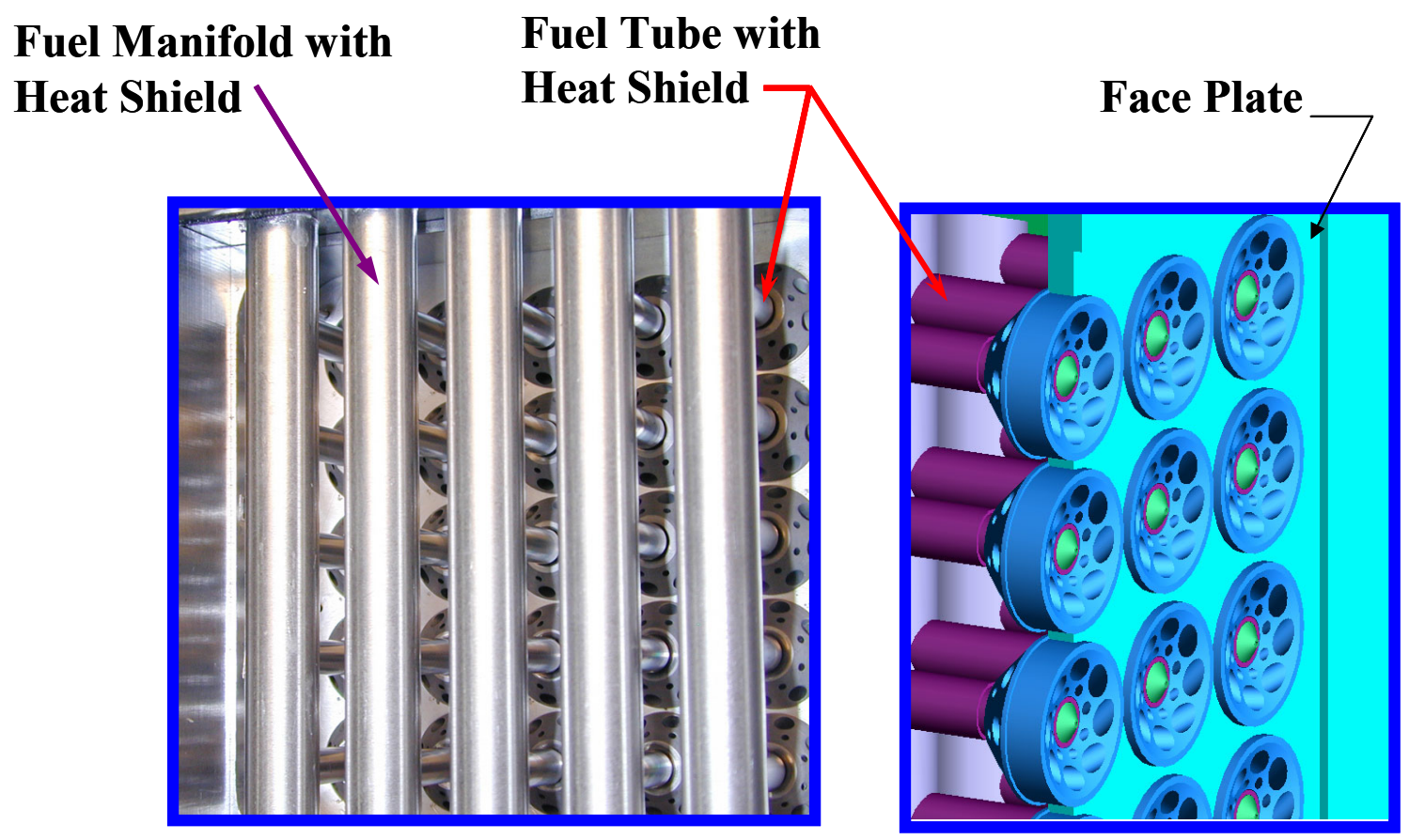

Figure 2 - 25-pt MPX injector a)upstream looking downstream, b) side view
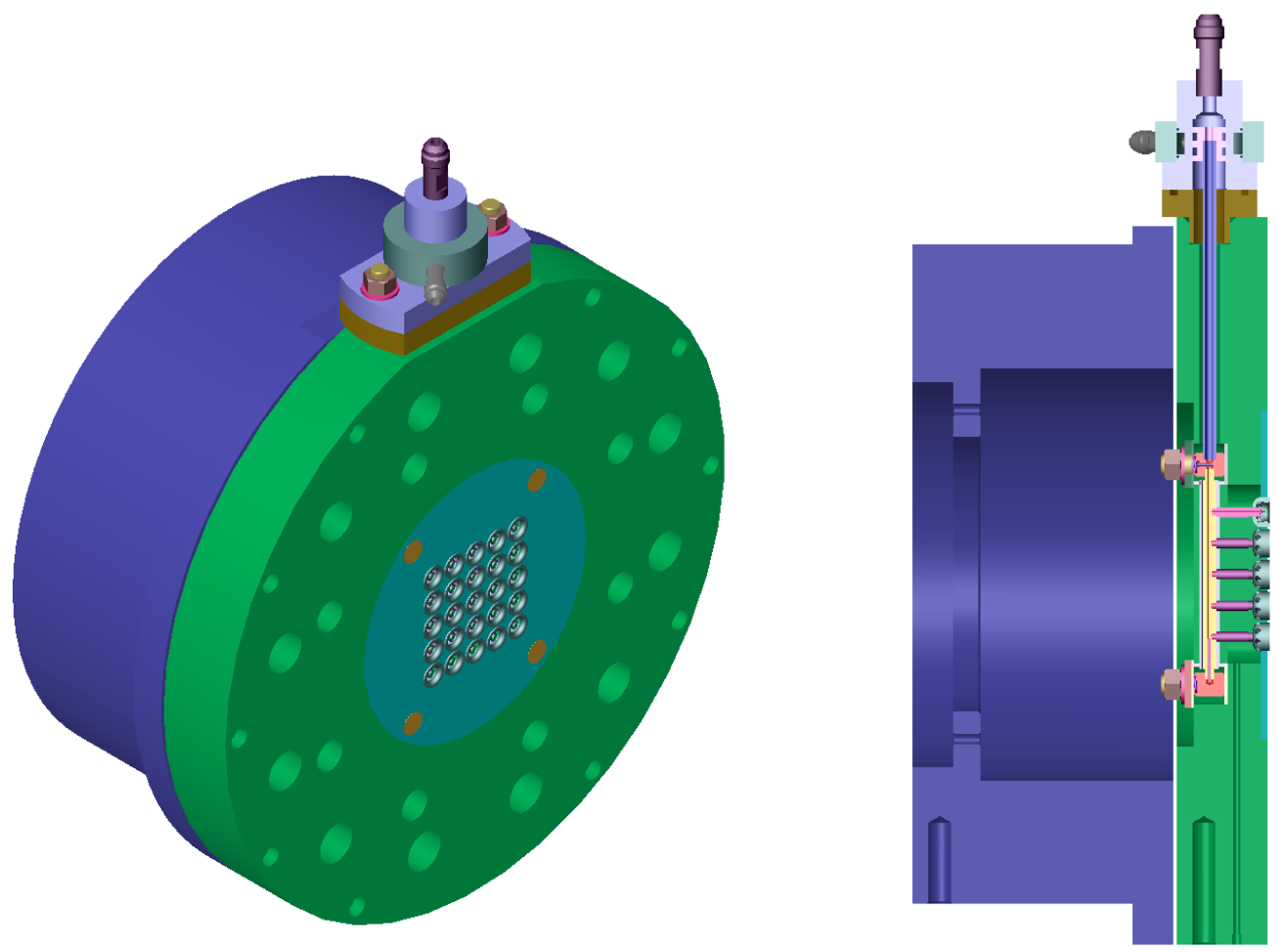

Figure 3 - Installation of fuel injector module 


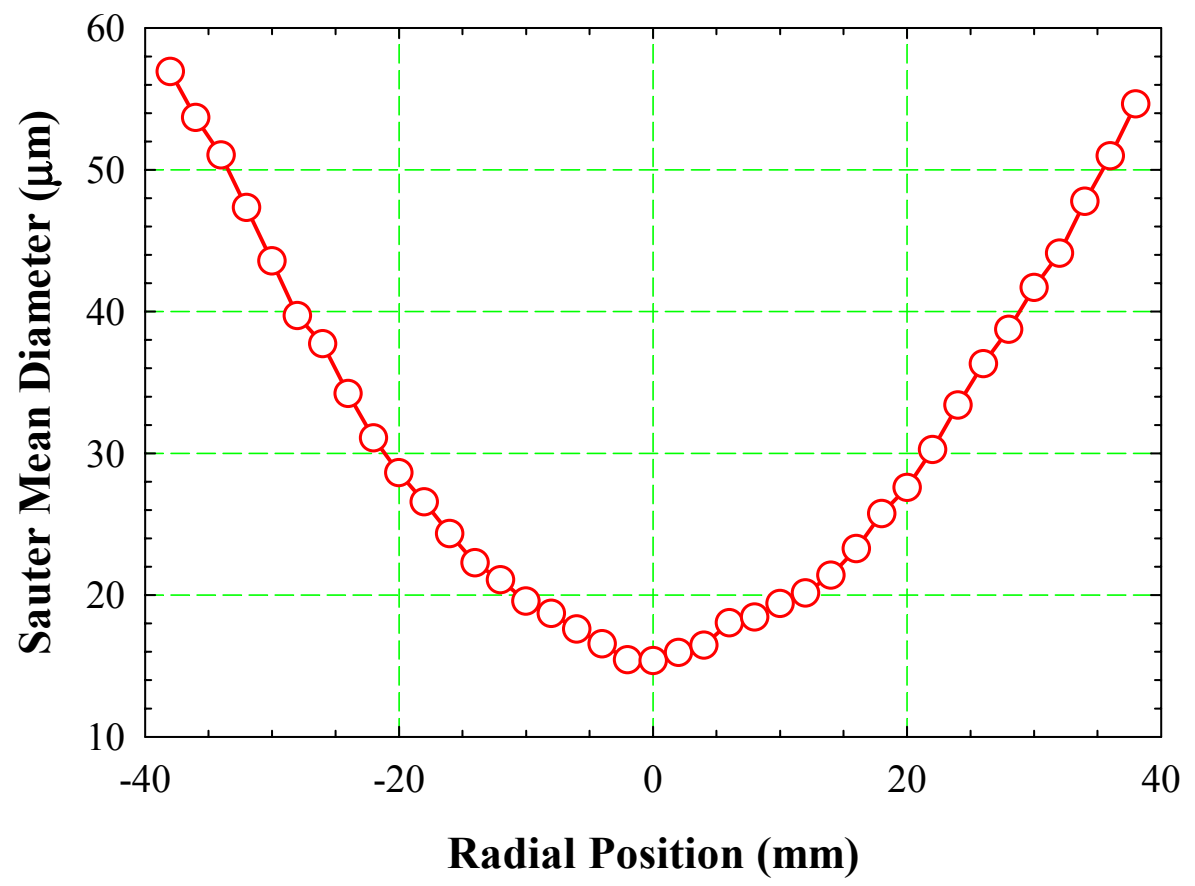

Figure 4a - Drop diameter distribution

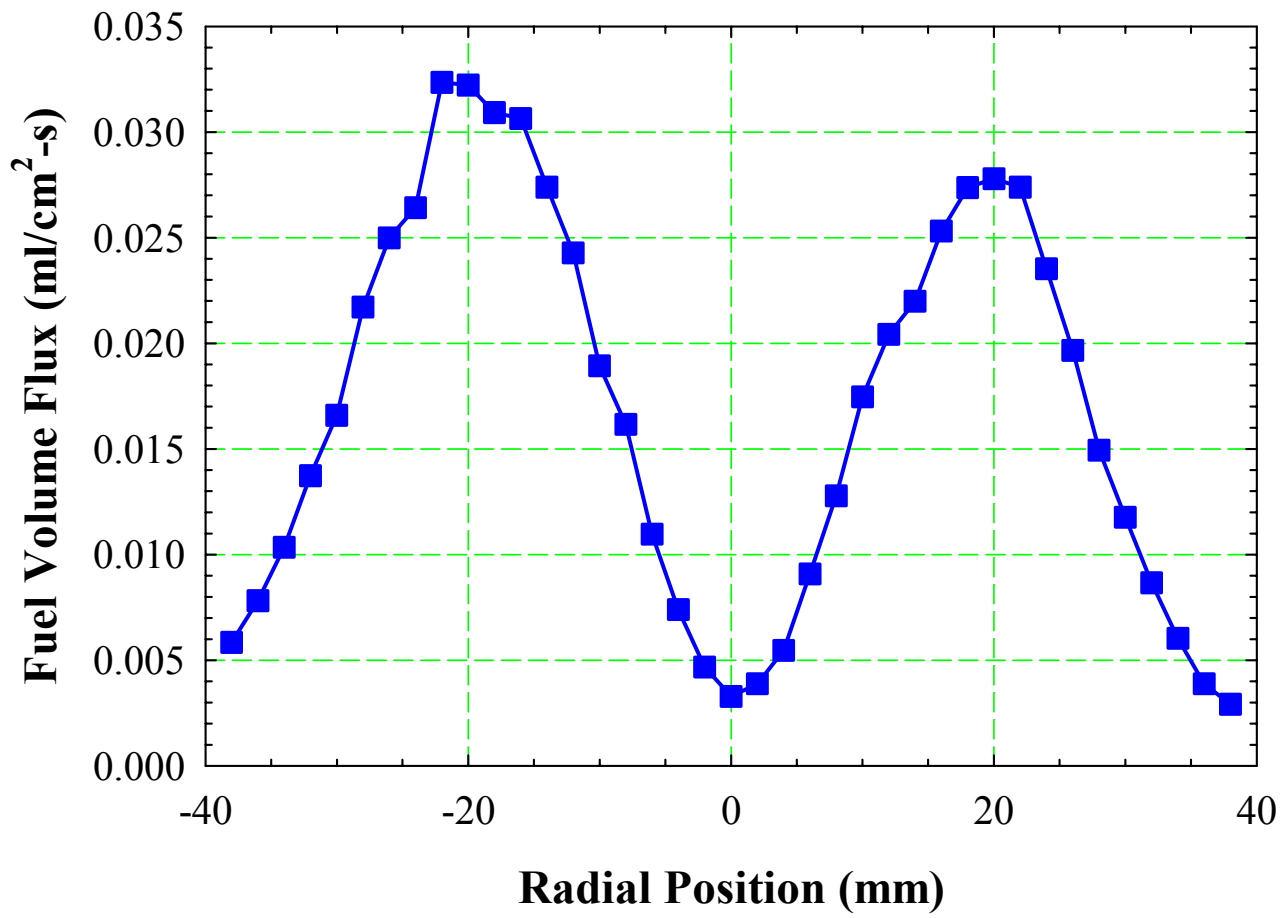

Figure $4 b$ - Fuel volume flux distribution

Figure 4 - Spray distribution characteristics 


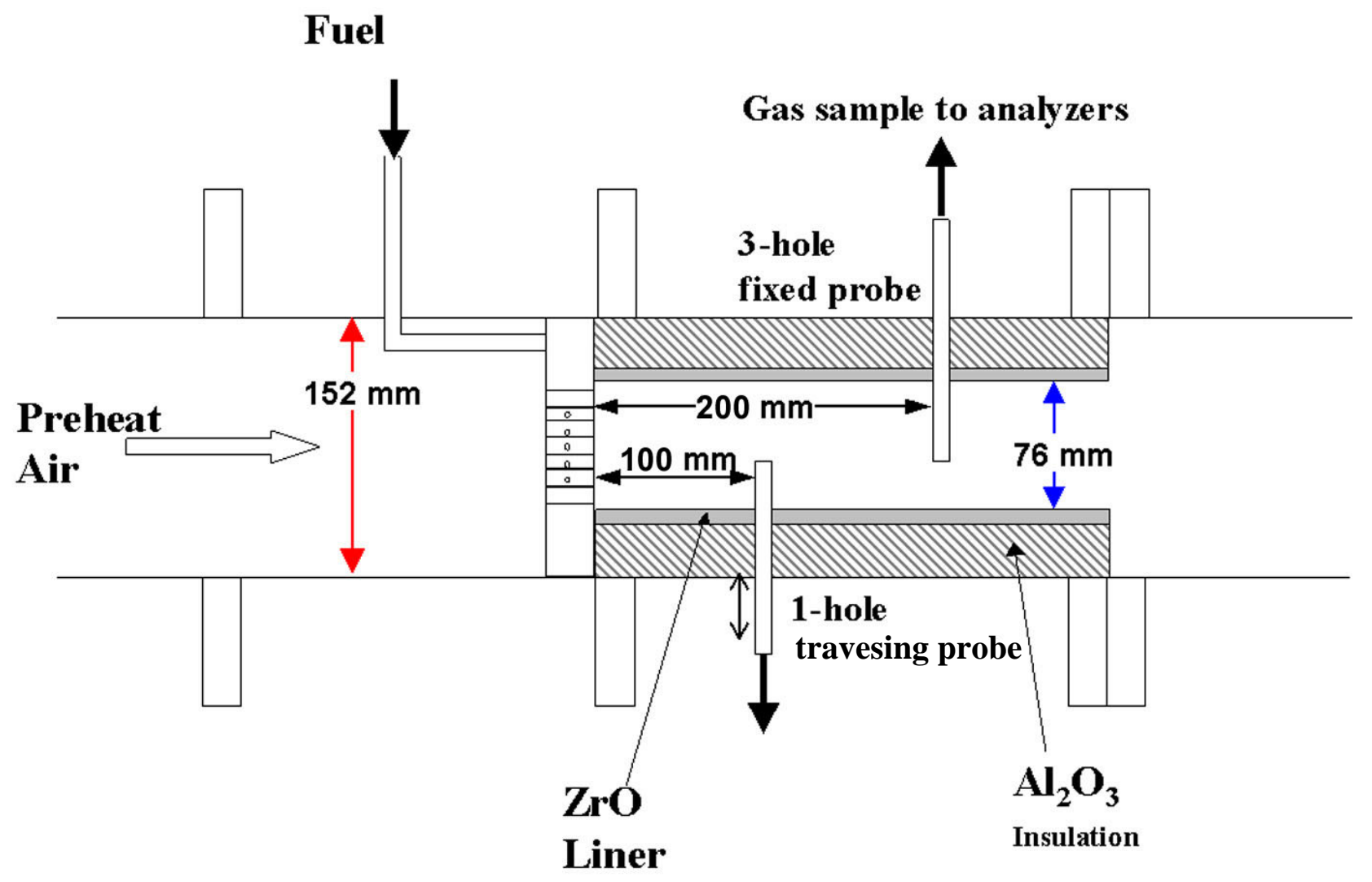

Figure 5 - Sketch of flame-tube test rig 


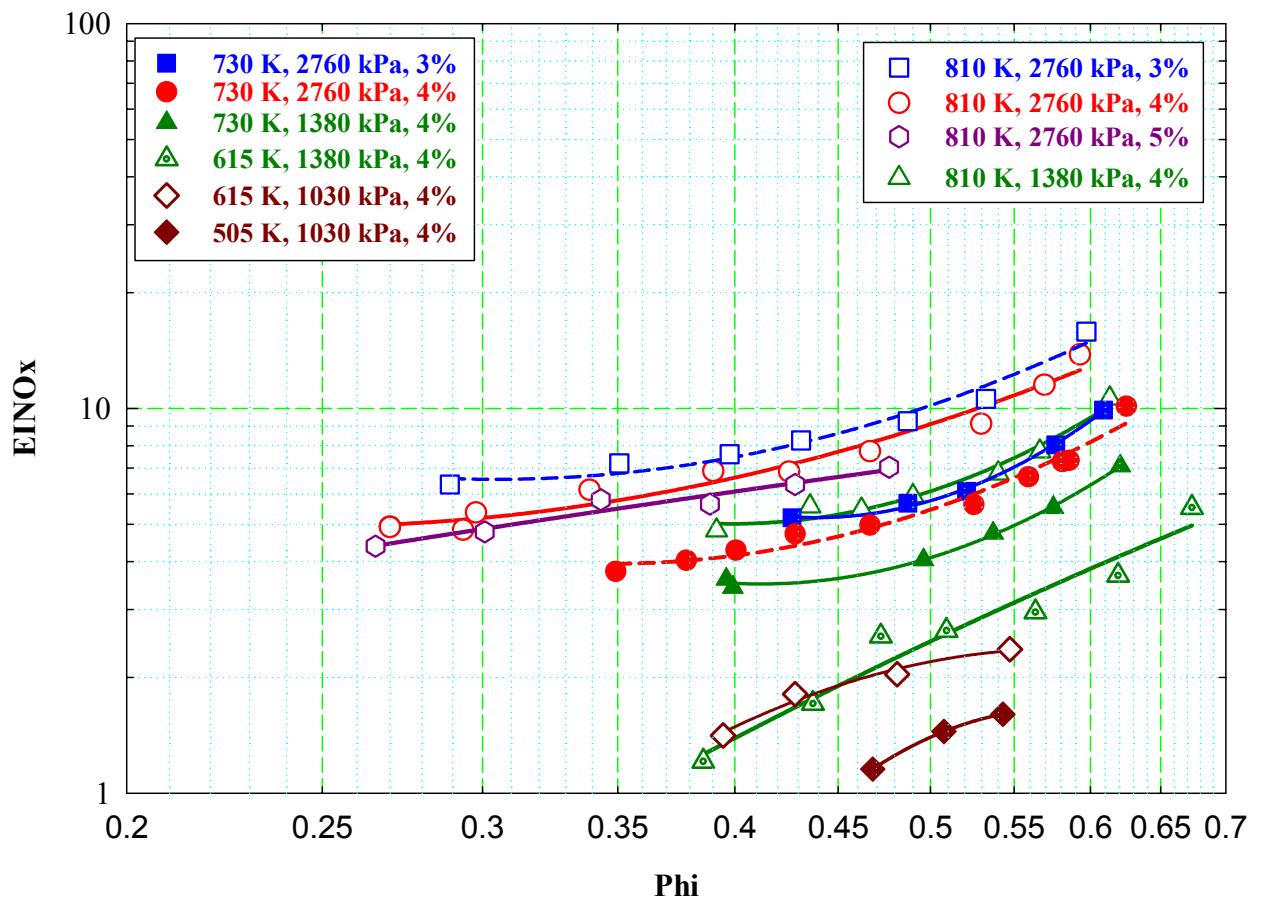

Figure 6a - NOx emission index versus equivalence ratio, Phi

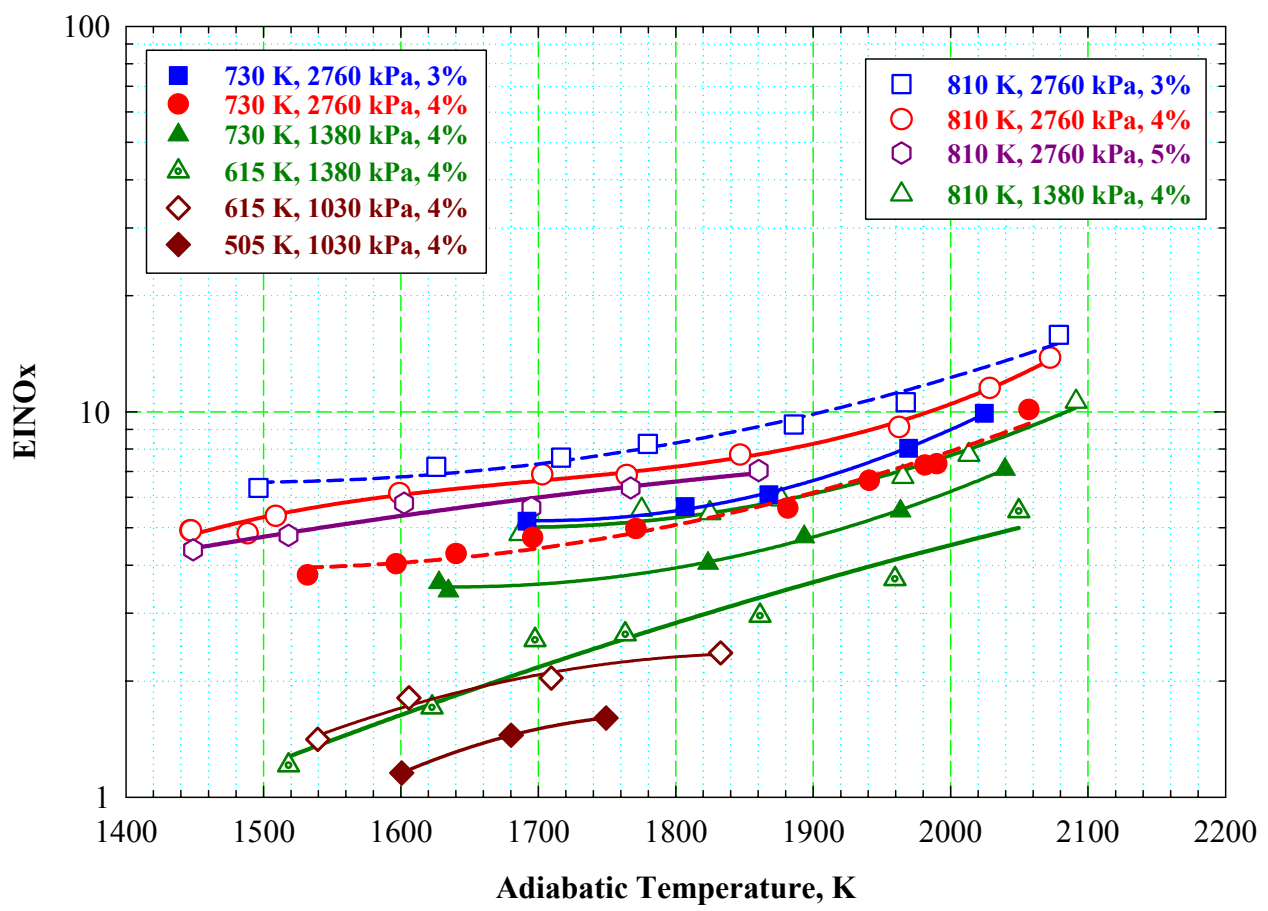

Figure 6b - NOx emission index versus adiabatic temperature

Figure 6 - NOx emissions 


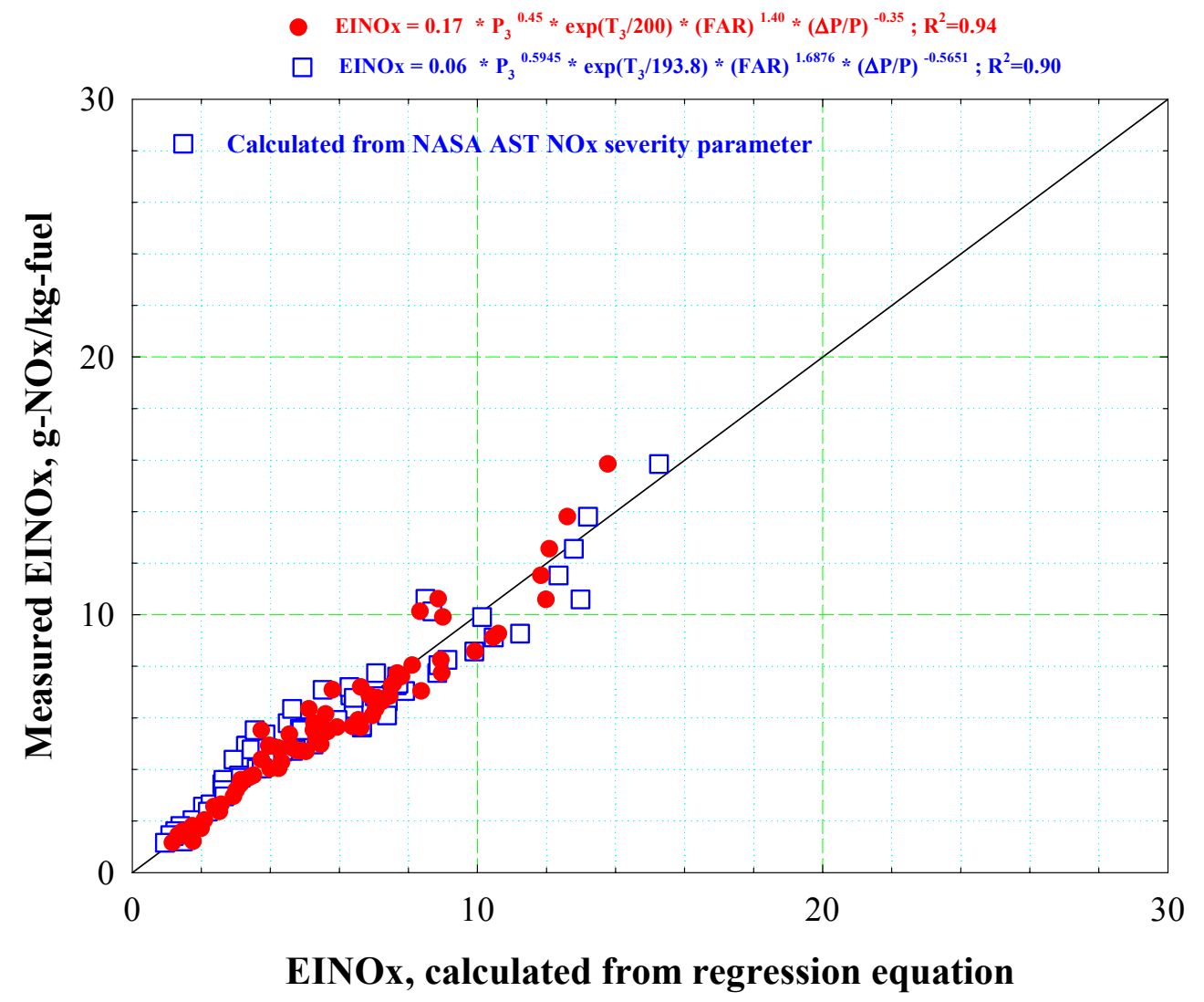

Figure 7 - NOx emission index correlation 


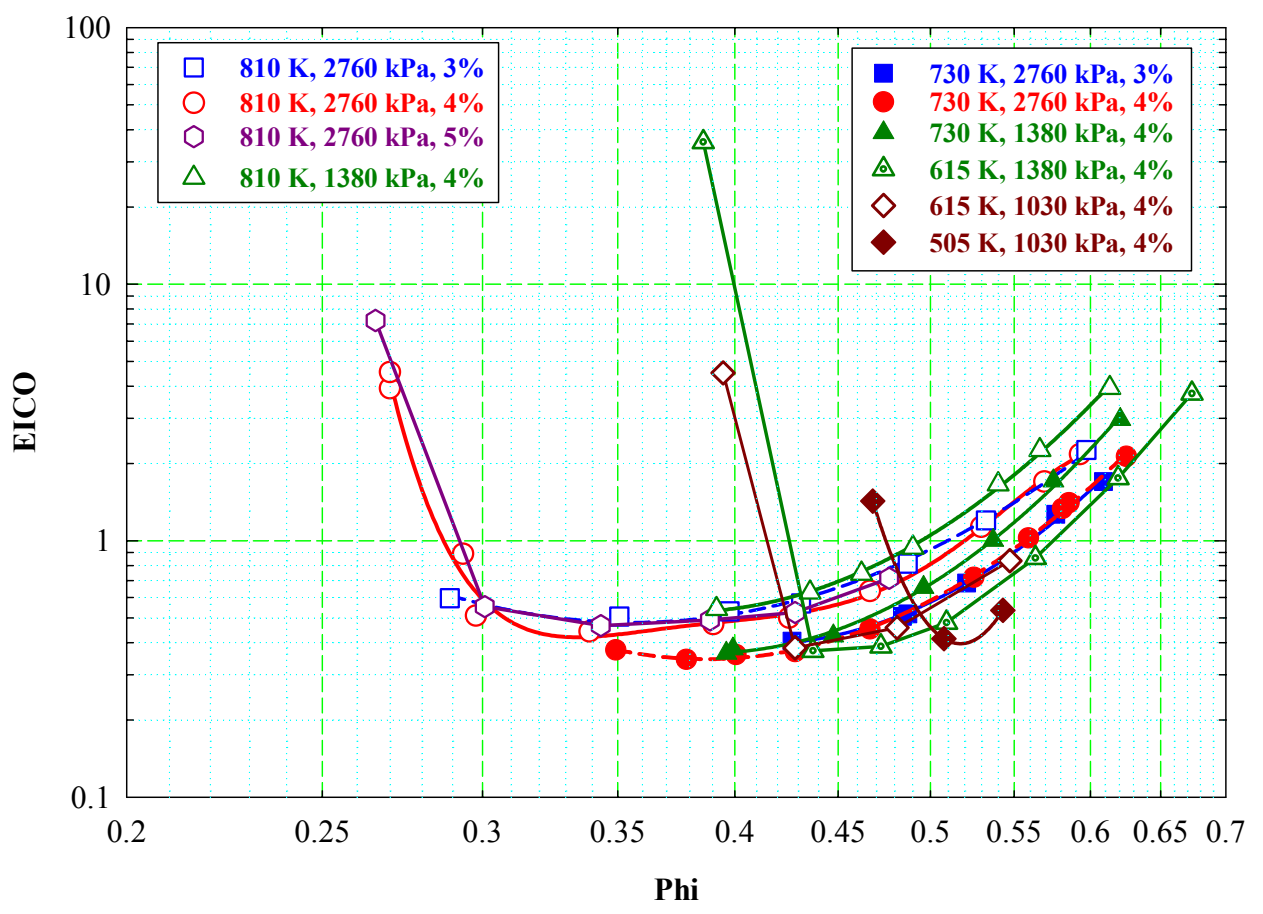

Figure 8a - CO emission index versus equivalence ratio, Phi

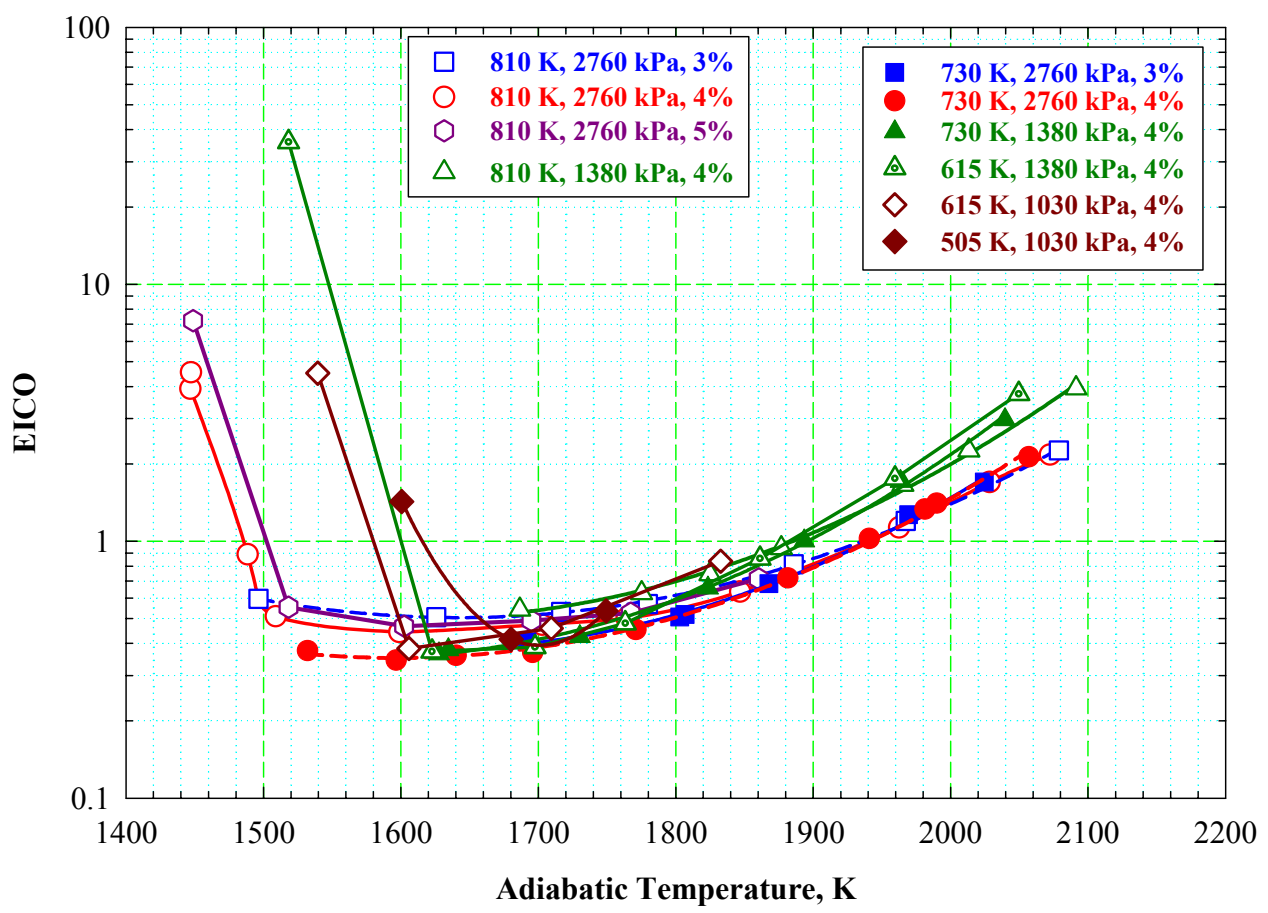

Figure 8b - CO emission index versus adiabatic temperature

Figure 8 - CO emissions 


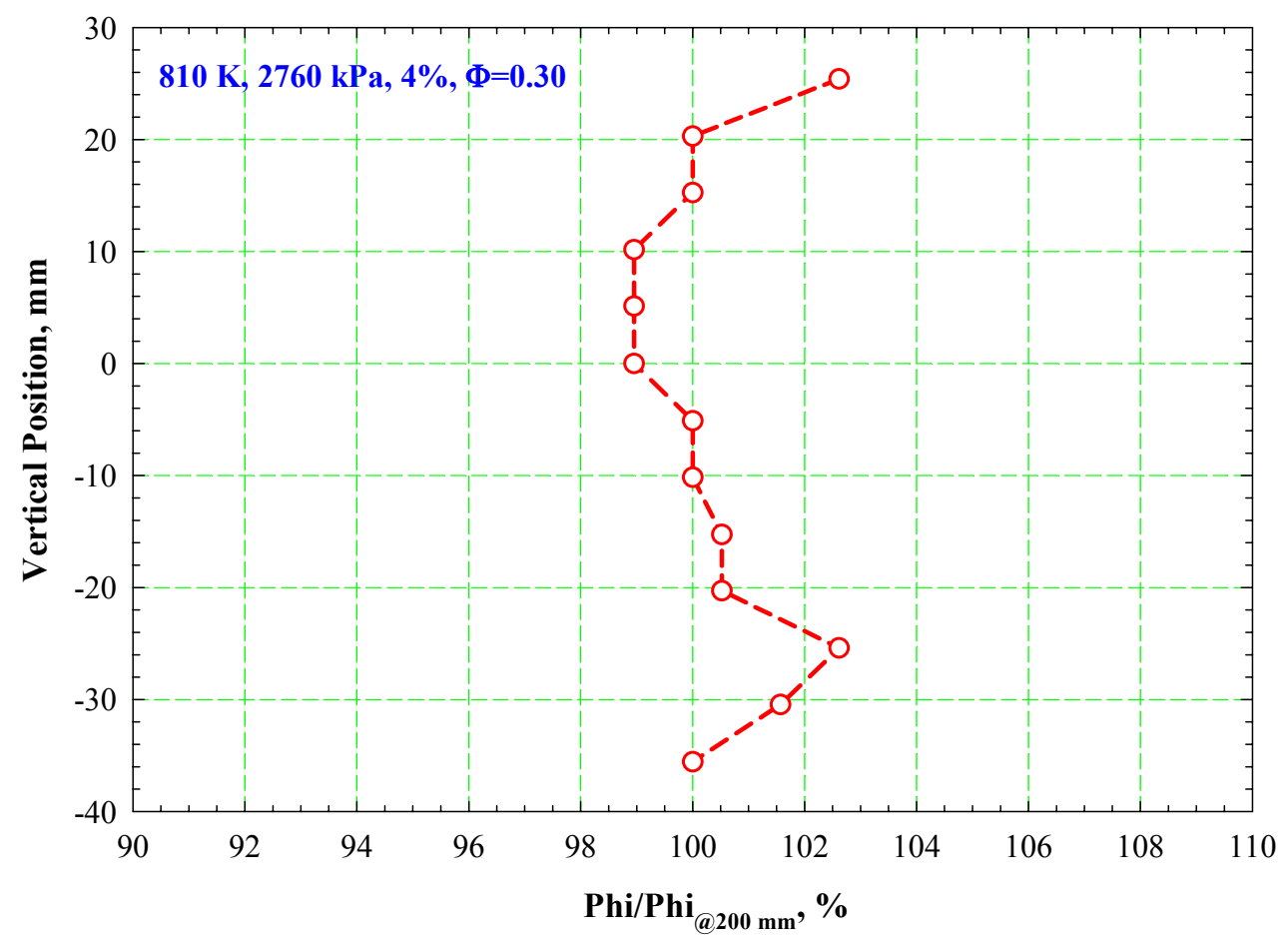

Figure 9a - Radial profiles of equivalence ratio at $100 \mathrm{~mm}$ downstream

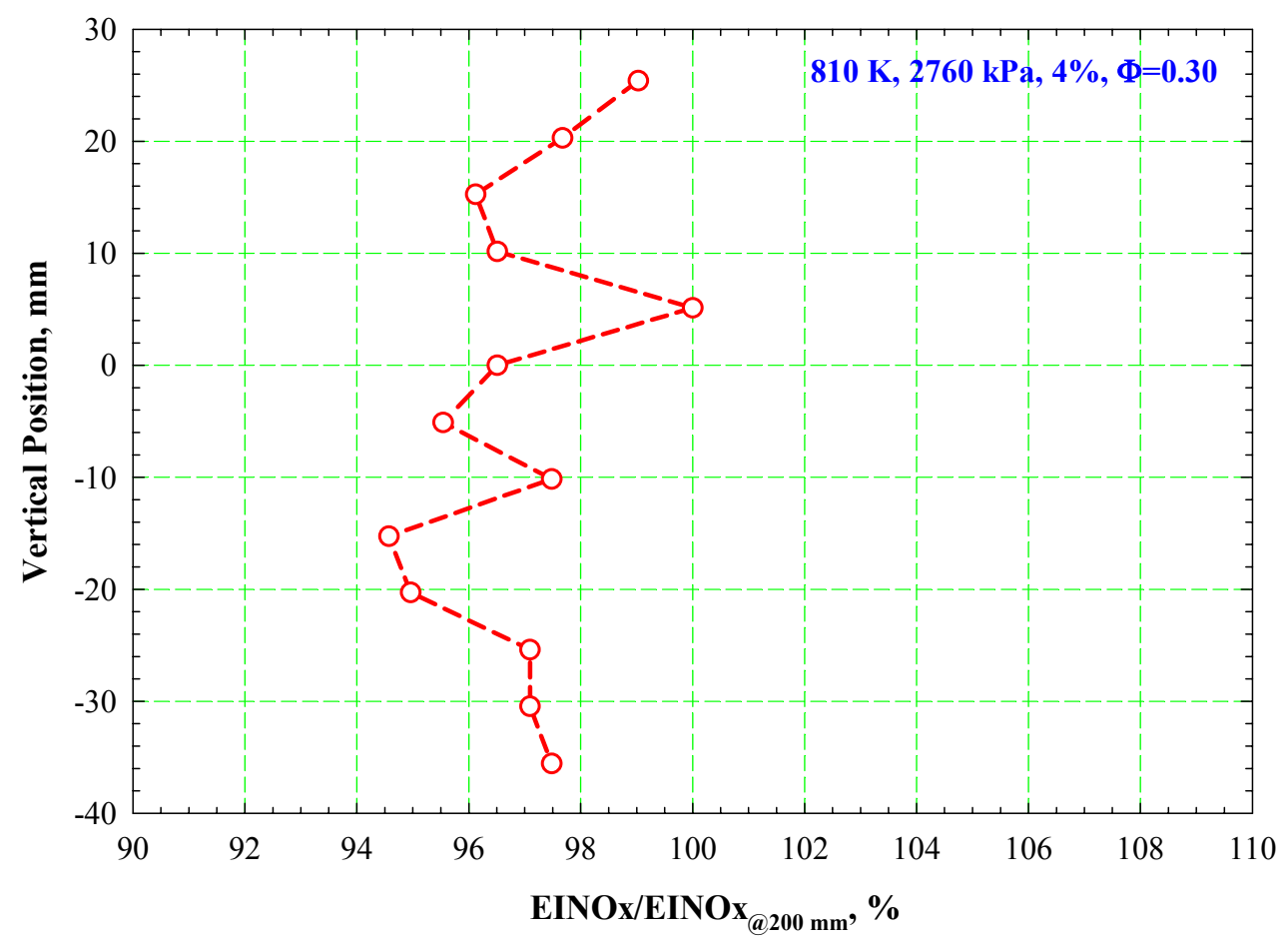

Figure 9b-Radial profiles of NOx emission index at $100 \mathrm{~mm}$ downstream Figure 9 - Radial profiles of emissions 


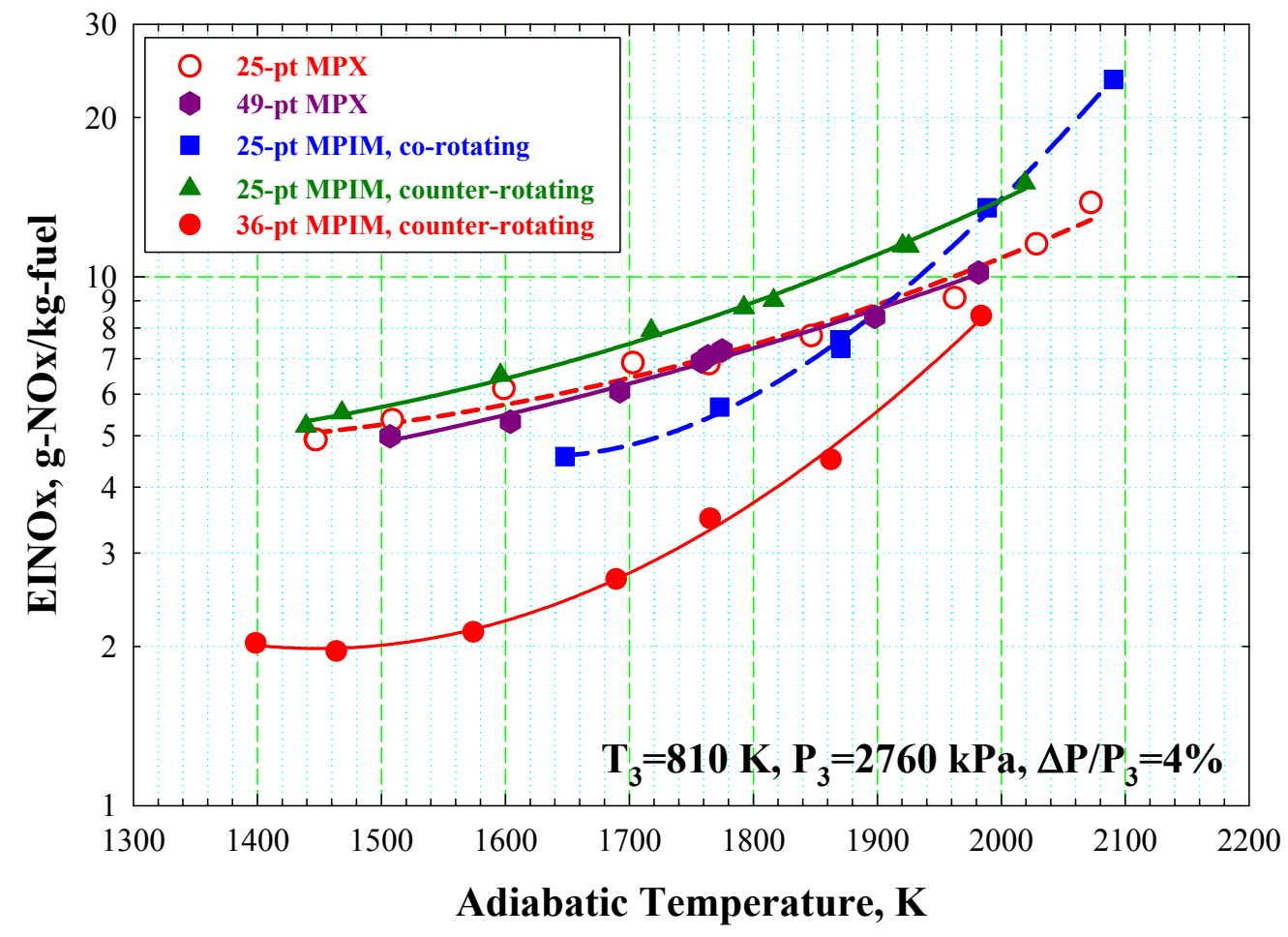

Figure 10 - Comparison NOx emission index to other multipoint configurations 
Public reporting burden for this collection of information is estimated to average 1 hour per response, including the time for reviewing instructions, searching existing data sources, gathering and maintaining the data needed, and completing and reviewing the collection of information. Send comments regarding this burden estimate or any other aspect of this collection of information, including suggestions for reducing this burden, to Washington Headquarters Services, Directorate for Information Operations and Reports, 1215 Jefferson Davis Highway, Suite 1204, Arlington, VA 22202-4302, and to the Office of Management and Budget, Paperwork Reduction Project (0704-0188), Washington, DC 20503.

1. AGENCY USE ONLY (Leave blank) 2. REPORT DATE 3. REPORT TYPE AND DATES COVERED

\section{TITLE AND SUBTITLE}

August 2004

Technical Memorandum

Experimental Investigation of a Multiplex Fuel Injector Module With Discrete Jet Swirlers for Low Emission Combustors 5. FUNDING NUMBERS

6. AUTHOR(S)

WBS-22-719-30-03

Robert Tacina, Chien-Pei Mao, and Changlie Wey

7. PERFORMING ORGANIZATION NAME(S) AND ADDRESS(ES)

National Aeronautics and Space Administration

John H. Glenn Research Center at Lewis Field

Cleveland, Ohio 44135-3191

8. PERFORMING ORGANIZATION REPORT NUMBER

E-14358

\section{SPONSORING/MONITORING AGENCY NAME(S) AND ADDRESS(ES)}

National Aeronautics and Space Administration

Washington, DC 20546-0001

10. SPONSORING/MONITORING AGENCY REPORT NUMBER

NASA TM-2004-212918

AIAA-2004-0185

\section{SUPPLEMENTARY NOTES}

Prepared for the 42nd Aerospace Sciences Meeting and Exhibit sponsored by the American Institute of Aeronautics and Astronautics, Reno, Nevada, January 5-8, 2004. Robert Tacina, NASA Glenn Research Center; Chien-Pei Mao, Turbine Fuel Technologies Goodrich Corporation, West Des Moines, Iowa 50265; and Changlie Wey, QSS Group, Inc., Cleveland, Ohio 44135. Responsible person, Robert Tacina, organization code 5830, 216-433-3588.

12a. DISTRIBUTION/AVAILABILITY STATEMENT

12b. DISTRIBUTION CODE

Unclassified - Unlimited

Subject Category: 07

Distribution: Nonstandard

Available electronically at http://gltrs.grc.nasa.gov

This publication is available from the NASA Center for AeroSpace Information, 301-621-0390.

13. ABSTRACT (Maximum 200 words)

A low- $\mathrm{NO}_{\mathrm{X}}$ emissions combustor concept has been demonstrated in flame-tube tests. A lean-direct injection (LDI) concept was used where the fuel is injected directly into the flame zone and the overall equivalence ratio of the mixture is lean. The LDI concept described in this report is a multiplex fuel injector module containing multipoint fuel injection tips and multi-burning zones. The injector module comprises 25 equally spaced injection tips within a 76 by $76 \mathrm{~mm}$ area that fits into the flame-tube duct. The air swirlers were made from a concave plate on the axis of the fuel injector using drilled holes at an angle to the axis of the fuel injector. The $\mathrm{NO}_{\mathrm{x}}$ levels were quite low and are greater than 70 percent lower than the 1996 ICAO standard. At an inlet temperature of $810 \mathrm{~K}$, inlet pressure of $2760 \mathrm{kPa}$, pressure drop of 4 percent and a flame temperature of $1900 \mathrm{~K}$ with JP8 fuel, the $\mathrm{NO}_{\mathrm{x}}$ emission index was 9 . The 25-point injector module exhibited the most uniform radial distribution of fuel-air mixture and $\mathrm{NO}_{\mathrm{x}}$ emissions in the flame tube when compared to other multipoint injection devices. A correlation is developed relating the $\mathrm{NO}_{\mathrm{x}}$ emissions to inlet temperature, inlet pressure, equivalence ratio and pressure drop.

14. SUBJECT TERMS

$\mathrm{NO}_{\mathrm{x}}$; Lean direct injection; Combustor emissions 19

\begin{tabular}{|c|c|c|}
\hline $\begin{array}{c}\text { 17. SECURITY CLASSIFICATION } \\
\text { OF REPORT } \\
\text { Unclassified }\end{array}$ & $\begin{array}{c}\text { 18. SECURITY CLASSIFICATION } \\
\text { OF THIS PAGE } \\
\text { Unclassified }\end{array}$ & $\begin{array}{c}\text { 19. SECURITY CLASSIFICATION } \\
\text { OF ABSTRACT } \\
\text { Unclassified }\end{array}$ \\
\hline
\end{tabular}

NSN 7540-01-280-5500

Standard Form 298 (Rev. 2-89) 

